\title{
Retrospective and prospective studies on helminthiases in bisons of Prioksko-Terrasny Nature Reserve (Moscow Region, Serpukhov District)
}

\author{
Olga A. Panova, Natalia V. Serdyuk*, Igor G. Glamazdin \& Irina I. Zemlyanko
}

ABSTRACT. Contemporary American bison (Bison bison (Linnaeus, 1758)) and European bison (Bison bonasus (Linnaeus, 1758)) are introduced (alien) species at the territory of Prioksko-Terrasny Nature Reserve. Presently, extensive interchange of parasitic fauna between the bisons and aboriginal ungulates is recorded, therefore, monitoring their helminth fauna appears to be a pressing issue. The current paper presents a survey of the helminth fauna in American bison and European bison based on the results of original research and literature data analysis. The investigation of faeces samples of American bisons from the nature reserve revealed eggs of Trichostrongylus sp. with length of $78.5 \mu \mathrm{m}$ and width of $40 \mu \mathrm{m}$ in size as well as those of Strongyloides papillosus (Wedl, 1856) with length of 60 and width of 20-22 $\mu \mathrm{m}$ in size. The eggs of Strongyloides papillosus in bisons from the nature reserve are recorded for the first time. It is supposed that the bisons contract this nematode species from sika deer (Cervus nippon Temminck, 1838), yet previously it was believed that deer and bisons are safe for each other in terms of helminthic infections. The study has shown the heterogenous composition of helminth fauna in contemporary American bison and European bison in different parts of their range, which appears to be connected with the circulation of helminthes among deers and bisons populating a particular area. The absence of highly specific, high-avid helminthes in the bisons has been found.

How to cite this article: Panova O.A., Serdyuk N.V., Glamazdin I.G., Zemlyanko I.I. 2017. Retrospective and prospective studies on helminthiases in bisons of Prioksko-Terrasny Nature Reserve (Moscow Region, Serpukhov District) // Russian J. Theriol. Vol.16. No.2. P.149-156. doi: 10.15298/rusjtheriol.16.2.04

KEY WORDS: Prioksko-Terrasny Nature Reserve, Central European bison breeding centre, Mammalia, Artiodactyla, Bison, helminth fauna, strongyloidoses.

Olga A. Panova [79161971494@yandex.ru], Federal State Budget Institution "All-Russian Scientific Research Institute of Fundamental and Applied Parasitology of Animals and Plants named after K.I. Skryabin”, B. Cheremushkinskaya St., 28, Moscow 117218, Russia; Natalia V. Serdyuk [natalyserdyu@yandex.ru], Borissiak Paleontological Institute, Russian Academy of Sciences, Profsoyuznaya str., 123, Moscow 117997, Russia; Igor G. Glamazdin [glamazdin@yandex.ru], Moscow State University of Food Production, Volokolamskoye road, 11, Moscow 125080, Russia; Irina I. Zemlyanko [zemlyankoirina@yandex.ru], Prioksko-Terrasny Nature Biosphere Reserve, Danki, Serpukhov district, Moscow region 142200.

\section{Ретроспективные и современные исследования гельминтозов бизонов Приокско-Террасного заповедника (Московская область, Серпуховский район)}

\author{
О.А. Панова, Н.В. Сердюк*, И.Г. Гламаздин, И.И. Землянко
}

РЕЗЮМЕ. Современные бизоны (Bison bison (Linnaeus, 1758)) и зубры (Bison bonasus (Linnaeus, 1758)) на территории Приокско-Террасного заповедника являются интродуцированными (завезенными) видами. В настоящее время идет активный взаимообмен паразитофауной между ними и аборигенными копытными, что делает актуальным мониторинг их гельминтофауны. В статье приводится обзор гельминтофауны бизонов и зубров, основанный на результатах собственных исследований и анализе литературных данных. При исследовании проб фекалий от бизонов с территории заповедника были обнаружены яйца Trichostrongylus sp. длиной $78.5 \mu \mathrm{m}$ и шириной 40 $\mu \mathrm{m}$, а так же яйца Strongyloides papillosus (Wedl, 1856) длиной $60 \mu \mathrm{m}$ и шириной 20-22 $\mu$. Яйца Strongyloides papillosus у бизонов Приокско-Террасного заповедника регистрируется впервые. Предполагается, что заражения бизонов данным видом нематоды происходит от пятнистых оленей (Cervus nippon Temminck, 1838). Ранее считалось, что олени и бизоны безопасны друг для друга в гельминтологическом отношении. Исследование показало неоднородность состава гельминтофауны современных бизонов и зубров в различных частях ареала, что связано с циркуляцией гельминтов между копытными и бизонами, обитающими на конкретной территории. Установлено отсутствие у бизонов видоспецифичных гельминтов.

КЛЮЧЕВЫЕ СЛОВА: Приокско-Террасный заповедник, Центральный зубровый питомник, Матmalia, Artiodactyla, Bison, гельминтофауна, стронгилоидозы.

* Corresponding author 


\section{Introduction}

Prioksko-Terrasny Nature Reserve (PTR) named after Mikhail A. Zablotsky was founded on 19th June 1945 and is a strict nature reserve. The reserve is located in the middle of the Central Russian Upland of the East European Plain, within the southern part of Moskvoretsko-Okskaya moraine erosion plain on the left-bank terraces of the Oka River. PTR is situated in the subzone of mixed coniferous and deciduous forests in the south-west of the Moscow Region on the border with broad-leaved forests. Adjacent territories house a two-km-wide protective zone with the total area of 4960 hectares, comprising the entire floodplain of the Oka, which adheres to the reserve's southern border and surrounding quarters of "Russkyi Les" forest district.

In 1948, the Central European Bison Breeding Centre $(\mathrm{EBBC})$ was established in the nature reserve. American bison (Bison bison (Linnaeus, 1758)) and European bison (Bison bonasus (Linnaeus, 1758)) are kept in conditions close to natural, at a forest site of about 200 hectares surrounded by a meshy fence. The breeding center area is divided into eight isolated enclosures. The animals apart from grazing are also provided compound formula feeds and woody forage (trunks and branches of aspen trees and willows). During winter season, animals are additionally provided with hay and root crops (carrots, beet roots). The entire area of the breeding centre is fenced and no access of livestock is ever possible. Currently, there are 66 European bisons of Caucasian and Belavezha origin and six American bisons living in PTR. Both, European and American bisons, are keeping in different isolated enclosures with fences and one meter buffer zone. The calves are reared in the reserve up to two years of age and then are relocated in newly created breeding centres as well as for range habitation.

Both bison species belong to the genus Bison Smith, 1827, which constitutes an independent phylogenetic lineage branching from the basal phylum of Bovina tribe in the upper Miocene (Sokolov, 1953). Starting from the early Pleistocene, the genus Bison appeared to be widely spread across the major part of Northern Eurasia. The representatives of the genus got across to North America no later than in mid-Pleistocene (McDonald, 1981). The contemporary European bison is a direct descendant of steppe bison (Bison priscus Bojanus, 1827) (Gromova, 1935). But Peter A. Lazarev (2009: 73-74) believes that the direct descendant of the prehistoric (steppe) bison is the contemporary American bison. However, there are other points of view regarding the origin of contemporary bisons, according to which the evolution followed the track of hybridization of Bos primigenius Bojanus, 1827 and Bison priscus (see Soubrier et al., 2016). Prevailing specific traits of Bison representatives are: the ability to adapt to the cold climate and diverse stations. Contemporary bisons populate various biotopes from steppes to alpine forests.
In Prioksko-Terrasny Nature Reserve bisons coexist with other 57 species, among which typical animals of the Russian plain are present. Ruminant artiodactyls are represented by deers: moose (Alces alces Linnaeus, 1758), sika deer (Cervus nippon Temminck, 1838), red deer (Cervus elaphus Linnaeus, 1758), roe deer ( $\mathrm{Ca}$ preolus capreolus Linnaeus, 1758), as well as the only species of suids - wild boar (Sus scrofa ferus Linnaeus, 1758).

The circulation of parasites among the hoofed animals in the reserve is inevitable, so the present work was aimed at studying the present-day parasitological conditions in the populations of PTR's ungulates, in particular, American bison and European bison.

\section{Material and methods}

Faeces were collected from the soil surface into special sterile containers; place and date of collection were indicated on the label. Only recently excreted (fresh) faeces - well-formed, with glossy surface, not affected by molds, free from insect larvae or pupae were taken (Samojlovskaja, 2011).

Six anonymized stool samples taken from EBBC's bisons were selected and studied. The parasitological assays were conducted within 24 hours of sampling.

The faeces were investigated according to Kotelnikov-Khrenov technique (Kotelnikov, 1984) using ammonia nitrate $(\rho=1.32)$ including the stage of centrifuging. Each stool sample was tested three times, with smaller samples taken from different parts of the larger one.

A three- to five-gram faeces sample was placed in a glass, a small amount of distilled water poured over it, then stirred thoroughly, strained through a metal sieve into a $50-\mathrm{ml}$ centrifuge test-tube. The sample was then centrifuged at $1000 \mathrm{rpm}$ for three minutes. The resulting sediment was mixed with $10 \mathrm{ml}$ of ammonia nitrate, transferred to $10-\mathrm{ml}$ centrifuge tubes and centrifuged at $1000 \mathrm{rpm}$ for three minutes. Then, a drop of the top film was removed by means of a loop and transferred to the slide for a microscopic study. The sediment obtained during centrifuging with the flotation solution was studied using formalin-acetate sedimentation.

Strongylate larvae were cultivated according to the Berman-Orlov technique. Parasites, eggs and helminth larvae were identified using species identification keys and monographs (Kozlov, 1977; Cherepanov et al., 2001).

\section{Results}

The investigation of faeces samples taken from American bisons of Prioksko-Terrasny Nature Reserve revealed eggs of Trichostrongylus sp. with length of $78.5 \mu \mathrm{m}$ and width of $40 \mu \mathrm{m}$ (Fig. 1) and eggs of Strongyloides papillosus (Wedl, 1856) with length of $60 \mu \mathrm{m}$ and width of 20-22 $\mu \mathrm{m}$ (Figs 2, 3).

Eggs of the nematode Strongyloides papillosus are recorded in PTR bisons for the first time. Strongyloidosis is studied to the greatest extent in sheep and goats 


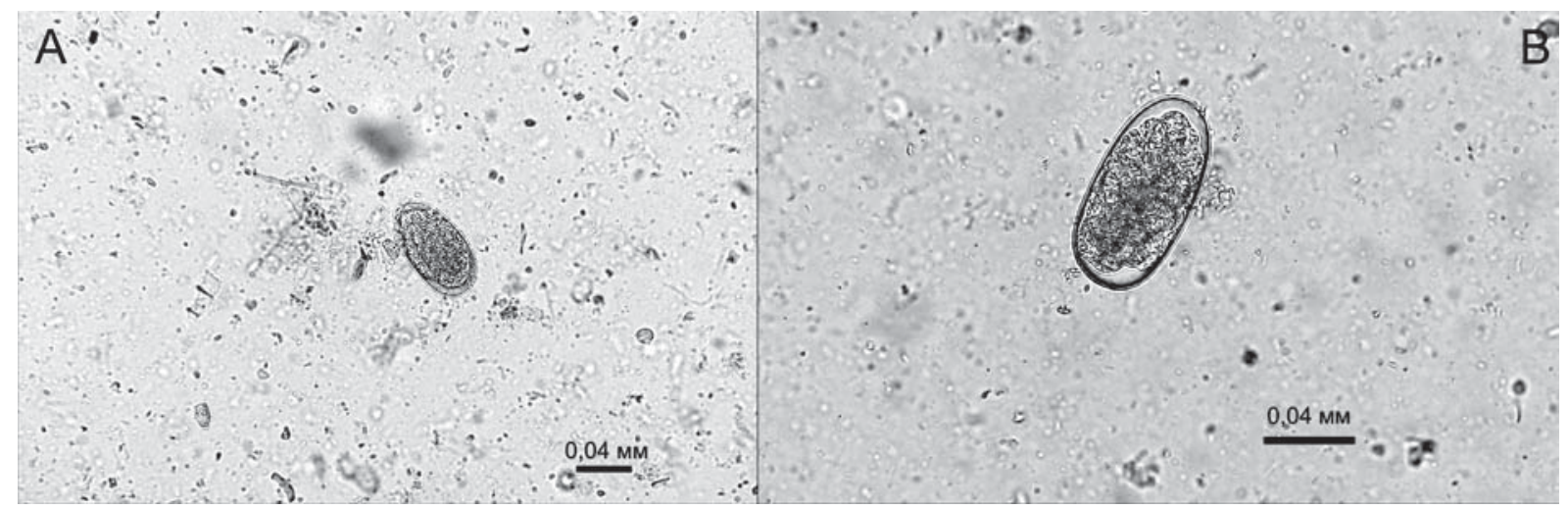

Fig. 1. Eggs of Trichostrongylus sp. from American bison of Prioksko-Terrasny Nature Reserve: A — egg with magnification x200; B - egg with magnification x400.

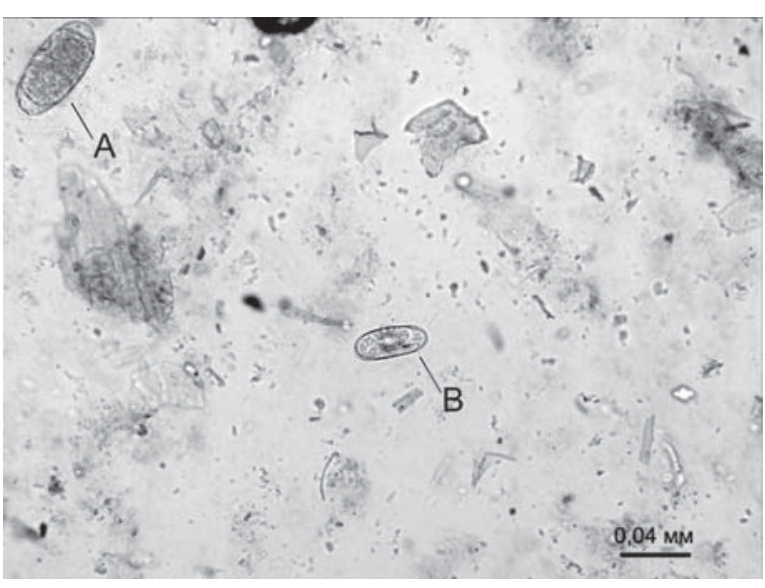

Fig. 2. Two different egg types of Strongyloides papillosus (Wedl, 1856) from American bison of Prioksko-Terrasny Nature Reserve: A — "large" type; B — "small" type. Magnification $\mathrm{x} 200$.

that can carry the causative pathogen for lifetime. In cattle, $S$. papillosus affects the young individuals up to one year old. It is stated that $S$. papillosus occurs in the small intestines (superficial layers of the mucous membrane, between the villi, under the epithelium) of ruminants.
Since contemporary bisons and European bisons are introduced (alien) species at the territory of Prioksko-Terrasny Nature Reserve, active exchange of parasitic fauna between them and indigenous ungulates is in progress nowadays.

\section{Discussion}

There is no literature available or there is paucity of literature about helminth fauna of wild ruminant in general and of bisons in particular at PTR. Nonetheless, the helminth fauna of contemporary artiodactyls in the European part of Russia (including species living in PTR) has been studied rather well (Gadaev, 2010; Litvinov et al., 2012; Muromtsev, 2012; Samojlovskaja, 2008, 2011). Below, the results of a comprehensive helminth research in the ungulates of Moscow region (Serpukhov and Lotoshino districts, "Losinyi Ostrov" (= "Moose Island") National Park, "Zavidovo" National Park), Vologda Region, Kaliningrad Region, Central Caucasus and Belarus (Table 1).

Moose is abundant throughout most of the territory of Russia. Moose helminth fauna is represented by 62 helminth species belonging to 42 genera and 20 families respectively (Pryadko, 1976). In the moose of Moscow Region, 38 helminth species have been found (Kuz-

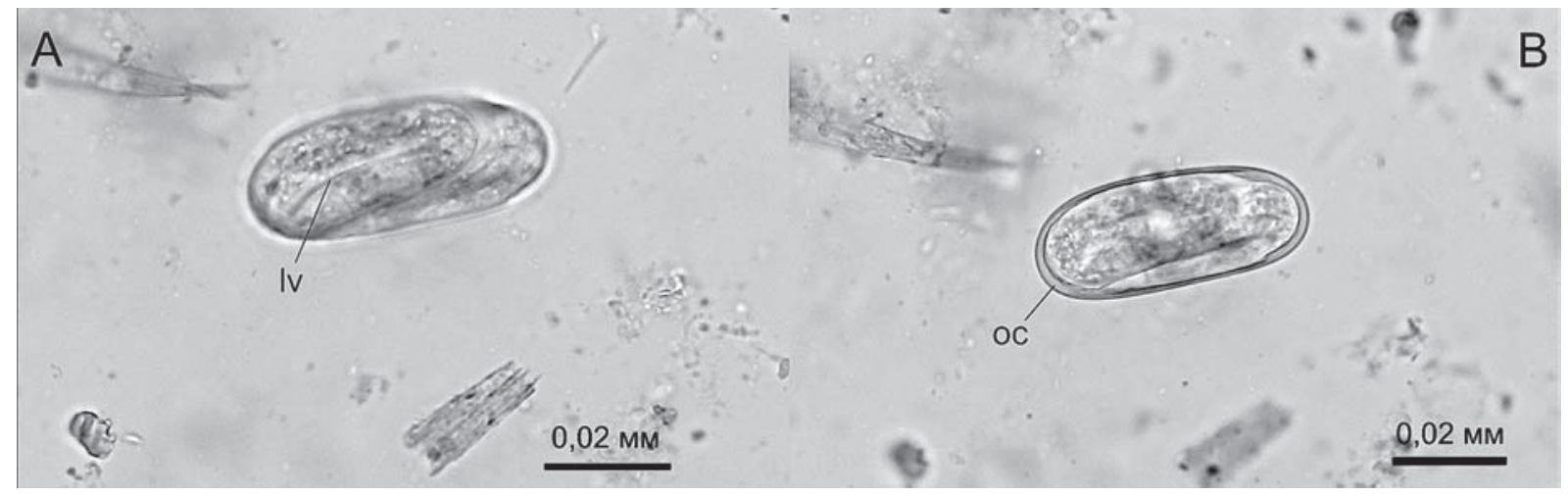

Fig. 3. Egg of S. papillosus from American bison of Prioksko-Terrasny Nature Reserve under the different levels of sharpen: A - view of the larva into egg (lv); B - common view of egg (show the outer cuticle, oc). Magnification x400. 


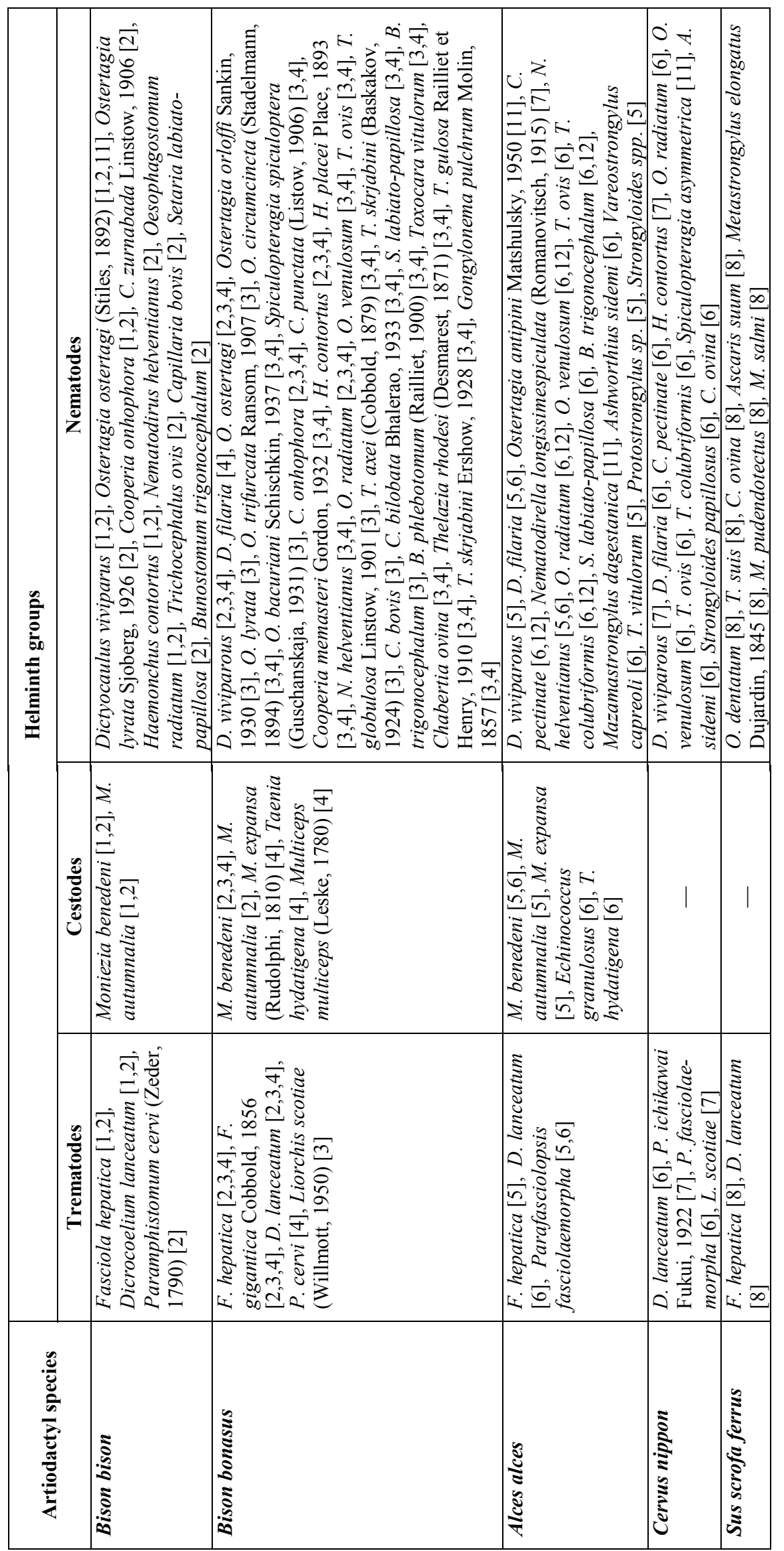


netsov et al., 2006). In 2006, two Trichostrongylidae species - Mazamastrongylus dagestanica (Altaev, 1953) and Ostertagia antipini Matschulsky, 1950 were reported in moose from Serphukhov and Lotoshino districts. The moose from Serpukhov district was found to possess only the first species. Nina Samojlovskaja (2008) detected two species of trematodes (Dicrocoelium lanceatum Stiles et Hassall, 1898, Parafasciolopsis fasciolaemorpha Eismont, 1932); two Cestoda species (Moniezia benedeni (Moniez, 1879), Echinococcus granulosus (Batsch, 1786) larvae, Taenia hydatigena Pallas, 1766 larvae) and 12 species of nematodes (Bunostomum trigonocephalum (Rudolphi, 1808), Cooperia pectinata Ransom, 1907; Dictyocaulus filaria $(\mathrm{Ru}-$ dolphi, 1809); Oesophagostomum venulosum Rudolphi, 1802; Oesophagostomum radiatum Rudolphi, 1803; Trichostrongylus colubriformis (Giles, 1892); Trichocephalus ovis (Abildgaard, 1795); Vareostrongylus capreoli Stroh et Schmid, 1938; Ashworthius sidemi Schulz, 1933; S. papillosus; Nematodirus spp.; Ostertagia spp.) in moose (Samojlovskaja et al., 2013).

In 2009, a study of material obtained from a moose from Vologda Region revealed 21 helminth species. They appeared to belong to three classes: Trematoda was presented by two species, Cestoda was presented by six species, and Nematoda by 13 species. Among them were: Fasciola hepatica Linnaeus, 1758, P. fasciolaemorpha, Moniesia expansa (Rudolphi, 1810), Moniesia autumnali Kuznetsov, 1967, Toxocara vitulîrum (Goeze, 1782), M. benedeni, pulmonary Strongylata of the following species: Dictyocaulus viviparus (Bloch, 1782), D. filaria, Protostrongilus spp., Nematodirus spp., Trichostrongilus spp., Ostertagia spp., Haemonchus spp., Oesophagostomum spp., Cooperia spp., Bunostomum spp., Strongyloides spp. (Shestakova \& Novikova, 2009).

According to the coprological examination of moose from "Losinyi ostrov" National Park undertaken in 2013, the following helminth species of the suborder Strongylata were identified: $B$. trigonocephalum, $C$. pectinata, O. venulosum, O. radiatum, T. colubriformis, Nematodirus sp., Ostertagia sp.

Sika deer is naturalized in various parts of European Russia. These animals are known to have diverse helminth fauna represented by 50 species, belonging to 34 genera and 16 families (Pryadko, 1976). In 1999, both in Zavidovo National Park and in the forest zone of Russia sika deer were found to possess 16 helminth species (Fertikov et al., 1999). The 39 helminth species were identified in sika deer in Eastern Europe (Govorka et al., 1988).

In 2008, two species of trematodes (D. lanceatum and $P$. fasciolaemorpha) were recorded in sika deer from "Losinyi ostrov" National Park. Ten species of nematodes were also detected, namely: Chabertia ovina (Fabricius, 1788), C. pectinata, D. filaria, Nematodirus spp., Ostertagia spp., O. venulosum, O. radiatum, T. colubriformis, T. ovis, $S$. papillosus. In a dissected corps of a sika deer, Ashworthius sidemi Schulz, 1933, D. filaria, T. ovis were identified (Samojlovska- 
ja, 2008). It was also reported that a sika deer in Serpukhov District carried Spiculopteragia asymmetrica (Ware, 1925) Orloff, 1933, and a bison had Ostertagia. ostertagi (Stiles, 1892) Ransom, 1907 (Kuznetsov et al., 2006).

Roe deer is a species with a wide range. The degree and intensity of infection directly correlates with biotopic conditions in the animal's habitats. In humid forests, the infection rate is much higher than in those with dry soils. In 2012 in Belarus, a roe deer was found to be infected with 48 species of parasitic worms, including six Trematoda, four Cestoda and 38 Nematoda species (Litvinov at al., 2012).

Helminth fauna in wild and domesticated suids comprises 139 species, the biggest number - 99 species parasitizing in domestic pig; wild boars are affected by 33 species (Mozgovoy, 1967). Wild boars populate many kinds of farming and hunting acreage. Crucial conditions for their existence are the availability of feeds and dense thickets to hide in.

Post-mortem helminthological examinations revealed that wild boars have two species of Trematoda - D. lanceatum and $F$. hepatica, and seven species of nematodes, such as: Ascaris suum (Goeze, 1782), C. ovina, Metastrongylus elongates (Dujardin, 1845), Metastrongylus pudendotectus Wostokow, 1905, Metastrongylus salmi Gedoelst, 1923, Oesophagostomum dentatum Rudolphi 1803, Trichocephalus suis (Schrank, 1788) - parasitizing in them (Samojlovskaja, 2011).

Results of years-long helminth fauna studies in American bison, European bison and their hybrids from the majority of former USSR's nature reserves are summarized in Table 1. In Prioskso-Terrasny Nature Reserve, such research has been performed since early 1960s, and, starting from September, 1968, parasitological monitoring of the animals is being conducted (Gorokhov et al., 1995; Moskvin \& Bagrova, 1993).

In 1995, European bison of EBBC was found to have 15 species of helminth (Tab. 1), out of them $-F$. hepatica, D. lanceatum, Moniezia autumnalia Kuznetsov, 1967, M. benedeni, D. viviparous, O. radiatum, O. ostertagi, Cooperia onhophora (Railliet, 1898), Haemonchus contortus (Rudolphi, 1803). All studied animals had strongyles, or palisade worms, in their gastrointestinal tracts, and $75 \%$ of them had strongylates. It is notable that the species composition of helminthes in EBBC's European bison, American bisons and crosses between them are identical to that of catlle and sheep (Gorokhov et al., 1995; Parasite coenoses, 1984).

In 1997, Natalia V. Treboganova pointed out that the helminth fauna in American bison and European bison had remained almost unchanged since the establishment of the breeding centre. The 17 helminth species were recorded. Three of them ( $F$. hepatica, $D$. lanceatum, Paramphistomum cervi (Zeder, 1790)) belong to Trematoda; $M$. benedeni and $M$. autumnalia belong to Cestoda; twelve species of Nematoda such as D. viviparus, O. ostertagi and Ostertagia lyrata Sjoberg, 1926, C. onhophora, Cooperia zurnabada Antipin,
1931, H. contortus, Nematodirus helventianus May, 1920, Oesophagostomum radiatum (Rudolphi, 1803), Trichocephalus ovis Abildgaard, 1795, Capillaria bovis (Schnyder, 1906), Setaria labiatopapillosa (Alessandrini, 1838) have been found also. Until 1992, there were records of B. trigonocephalum in European bison, too (Treboganova, 1997).

In order to obtain the full scope of information on the parasite fauna in European bison, research on European bison population in Belovezhskaya Pushcha (Belavezha Forest) of 1919 has been analyzed (Kulagin, 1919). But since the population is entirely extinct, and, therefore, excluded from the biological interaction in the nature, the data on helminthes were not included in Table 1. The European bison of Belavezha were said to have such trematodes as $F$. hepatica, D. lanceatum, Paramphistomum sp.; their cestodes were E. granulosus, cysticerci of Taenia marginata Batsch, 1786, as well as three Moniezia species (species not stated). Nematodes found in those bisons were $D$. viviparus, $C$. oncophora, O. venulosum, rarely - Trichocephalus affinis Rudolphi, 1801, S. labiato-papillosa, H. contortus, recognized as rather common, Gongylonema scutatum Leuckart, 1873.

All in all, it is pointed out that American bison and European bison, not only in PTR but in also in other nature reserves, appear to have the same helminth fauna as other ungulates (Anisimova et al., 2008; Bagrova et al., 1995; Gorokhov et al., 1995; Subbotin, 2011; Treboganova, 1997): the leading ones are helminthes of farm ruminants, the next are parasites of deer, caprids, suids and canines. Such a heterogeneous endoparasite fauna can be explained by the loss of previous specific parasite fauna by the prehistoric bison Bison priscus. The composition of the helminth fauna of every animal species is primarily determined by the geo- and biocoenotic conditions of the region (Dogiel, 1947), and any changes to it will influence the faunal list. Thus, a population of prehistoric bisons, influenced by biotic and abiotic factors, firstly lost its high density (which led to depletion of its parasite fauna) and then ceased to exist completely. The absence of specific flat worms in the descendants of Bison priscus also indicates the extinction of prehistoric fauna, in particular, intermediate hosts of Trematoda and Cestoda. This standpoint explains the presence of worms from the superfamily Trichostrongilildae (Cooperia oncophora, Cooperia bisonis, Ostertagia bisonis, O. ostertagi, Dictyocaulus viviparous, Haemonchus contortus), which are, according to some authors (Kozlov \& Nazarova, 1979; Treboganova, 1997), are the most adapted to parasitizing in American bison and European bison. All these helminthes are known to have the direct developmental cycle, when infection is performed by the tertiary larvae, therefore they can have quite a wide range of hosts.

The formation of species-specific helminth fauna is a time-expanded process, and it is not always possible to track and trace it due to rare findings of ancient helminthes. When such findings do take place, it is 
always a remarkable occasion generating steady interest. Thus, a frozen mummy of a prehistoric bison, found in 1971 on the right bank of the Indigirka river, contained two preserved nematodes, described as a new species Skrjabinagia paleobisonica (Shakhmatova, 1988) and later revised as Ostertagia paleobisonica Shakhmatova, 1988. At different times, parasitologists indicated different types of helminthes as specific for American bisons and European bisons (Rukhlyadev, 1967; Treboganova, 1997). But Vera I. Shakmatova points out the resemblance of that new fossil species and previously described extant one from the intestines of contemporary American bison (Chapin, 1925), noting that nematodes of this genus are differentiated into species by their hosts and finding locations. Possibly, it is worthwhile to consider Ostertagia bisonis and Cooperia bisonis specific for contemporary bisons.

So, finding eggs of $S$. papillosus in bison faeces requires additional studies and explanations. Helminth fauna of modern wild ungulates is influenced by livestock grazing in the forested lands, deforestation, massive uptake of land for private use, increased number of people using forested areas for recreation (Rykovsky, 1974). Diseased animals are the main source of strongyloid infection. The invasive larvae in the environment migrate along plant leaves and stems and in the moist soil, retaining their vitality for three to four months. The animals, including the bisons, get infected on the pasture. The bulk of invasive elements accumulate on the feeding grounds, resting places and rubbing posts (Treboganova, 2003; Treboganova et al., 2005). Also, paths are not of the least importance in the accumulation of infective incipience as the bisons, when moving along their territory; keep strictly to the paths, following each other (Treboganova et al., 2005). However, presently the entire territory of the EBBC is fenced so the access of livestock to it is near-impossible.

S. papillosus was found in sika deer in the national park "Losinyi ostrov" in 2008 (Samojlovskaja, 2008), while in 2009 Strongyloides spp. was revealed in moose in Vologda region (Shestakova \& Novikova, 2009). According to Alexander N. Mosenkov (2011), moose readily move following the bison's paths being attracted by alkaline soils (solontzi) and bisons' lying sites as well as by the possibility to hide their traces and smell from wolves and hunting dogs among bisons' and European bisons' traces This information affords grounds for a suggestion that the bisons of PTR may contract the infection from sika deer or moose. Previously it was believed that deer and bisons are safe for each other helminthologically (Kozlov \& Nazarova, 1979). Also, small ruminants from private subsidiary farms of PTR staff cannot be ruled out as a possible source of infection.

\section{Conclusion}

The analysis of relevant literature and original research results shows that bisons lack species-specific helminthes which is likely to be explained by the ex- tinction of the ancestor of contemporary bisons and the sparsity of their present-day population. The composition of the helminth fauna in contemporary American bison and European bison is found to be heterogeneous and quite diverse in different parts of their range, which is connected with the circulation of helminthes among bisons and ungulates populating the same territory. It seems probable that currently the formation of helminth fauna in Prioksko-Terrasny Nature Reserve American bison and European bison is in progress. In this relation, our future efforts are aimed at investigating presentday parasitological conditions in other species of Prioksko-Terrasny Nature Reserve.

\section{ACKNOWLEDGMENTS}

The authors would like to thank Dr. Abdul Qayoom Mir for valuable comments. This study was supported by the Program of the Presidium of Russian Academy of Sciences "Exploratory Fundamental Research for Development of the Russian Arctic" in 2015-2017.

\section{References}

Anisimova E.I., Kekshina A.M., Kotlerchuk S.V. \& Poloz S.V. 2008. [Species composition of helminthes in the different populations of the Belovezhskiy Bison in Belarus] // Galaktionov K.V. \& Dobrovolskyi A.A. (eds.) Materialy IV Vserossiyskogo s'ezda Parazitologicheskogo Obschestav pri RAN. Sankt-Petersburg: Izdatel'stvo Lema. P.27-30 [in Russian].

Bagrova N.V., Gordeeva L.N., Moskvin A.S., Gorochov V.V. \& Novikova T.V. 1995. [Associations of parasites in the European bison and American bison during the parasitological monitoring in the Prioksko-Terrasny Nature Reserve] // Materialy dokladov nauchnoi konferencii "Associativnye parasitarnye bolezni, problem ecologii i terapii"]. Moscow. P.16-18 [in Russian].

Chapin E.A. 1925. New nematodes from North American mammals // Journal of Agricultural Research. Vol.30. No.7. P.677-681.

Cherepanov A.A., Moskvin A.S., Kotelnikov G.A. \& Khrenov V.M. 2001. [The Atlas of differential diagnostics of helminthiases according to the morphological structure of eggs and larvae of pathogens]. Moscow: Izdatel'stvo Kolos. 76 p. [In Russian]

Dogiel V.A. 1947. [The general Parasitology course]. Leningrad: Izdatel'stvo Gosuchpedgis. 372 p. [In Russian]

Fertikov V.I., Sonin M.D., Rykovskiy A.S. \& Egorov A.N. 1999. [Helminths of wild ungulates of the National Park "Zavidovo" and the forest zone of Russia]. Tver: Tverskaya Oblastnaya Tipographia. 80 p. [In Russian]

Gadaev H.H. 2010. [Fauna of nematodes of roe deer (Capreolus capreolus) in the Central Caucasus] // Russian Journal of Parasitology. No.4. P.9-11 [in Russian, with English summary].

Gorokhov V.V., Bagrova N.V., Gordeeva L.M., Moskvin A.S. \& Lubavin V.S. 1995. [Parasitological monitoring of the bison population] // Veterinariya. No.12. P.32-36.

Govorka Ya. P., Maklakova L.P. \& Mituh Ya. 1988. [Helminthes of the wild ungulates in East Europe]. Moscow: Izdatel'stvo Nauka. 208 p. [In Russian] 
Gromova V.I. 1935. [The steppe bison (Bison priscus Bojanus) in the USSR] // Trudy Zoologicheskogo instituta AN SSSR. Vol.2-3. P.1-204 [in Russian].

Kotelnikov G.A. 1984. [Helminthological studies of animals and environment]. Moscow: Izdatel'stvo Kolos. 208 p. [in Russian]

Kozlov D.P. 1977. [A guidebook of the helminthes of carnivora mammals in SSSR] Moscow: Izdatel'stvo Nauka. 257 p. [in Russian]

Kozlov D.P. \& Nazarova N.S. 1979. [Helminth's fauna of the European bison and the ways of its formation] // Sokolov V.E. (ed.). [European bison. Morphology, Systematics, Evolution, Ecology]. Moscow: Izdatel'stvo Nauka. P.471-475 [in Russian].

Kulagin N.M. 1919. [European bisones of Belovezhskaya Pushcha]. Moscow: Izdatel'stvo Cinema. 166 p. [In Russian]

Kuznetsov D.N., Lomakin V.V., Moskvin A.S. \& Treboganova N.V. 2006. [About the species list of trichostrongylides from domestic and wild ruminants in the Moscow region] // Trudy Vserossyiskogo instituta gelmintologii. Vol.42. P.173-177 [in Russian].

Lazarev P.A. 2009. [Lage mammals of the Anthropogene of Yakuia]. Novosibirsk: Izdatel'stvo Nauka. 159 p. [In Russian]

Litvinov V.F., Karasev N.F., Penkevich V.A., Lipnickyi S.S \& Kozorez A.I. 2012. Fauna of parasites of European roe (Capreolus capreolus L., 1788) in Belarus // Trudy Belorusskogo Gosudarstvennogo Tekhnologicheskogo universiteta. No.1. P.102-104 [in Russian, with English summary].

McDonald J.N. 1981. North American Bison. Their classification and Evolution. Berkeley, Los Angeles, London: University of California Press. 316 p.

Mosenkov A.N. 2011. [Technology of reproduction of freeliving bison in the Ust-Kubensky district of the Vologda region]. PhD Thesis. Vologodskaya Gosudarstvennaya Molochnokhozyaistvennaya Akademiya imeni N.V. Vereschagina. 20 p. [In Russian]

Moskvin A.S. \& Bagrova N.V. 1993. [Fauna of helminthes of European bisones in the Prioksko-Terrasny Nature Reserve] // Kudriavtsev I.V. (ed.). K voprosu o sokhranenii zubrov v Rossii. Puschino: Izdatel'stvo Puschinskogo Nauchnogo Centra. P.90-95 [in Russian].

Mozgovoi A.A. 1967 [Helminthes of domestic and wild pigs and diseases caused by them]. Moscow: Izdatel'stvo Nauka. 540 p. [In Russian]

Muromtsev A.B. 2012. [Parasitocenosis of domestic and wild ruminant animals in the Kaliningrad region] // Teoriea i practica parasitarnyh boleznei zhivotnyh. No.13. P.260-263 [in Russian].

Pryadko A.I. 1976. [Helminthes of deer]. Alma-Ata: Izdatel'stvo Nauka. 224 p. [In Russian]
Rukhljadev D.P. 1967. [On the helminth fauna of relict animals. Parasitic worms of bisons] // Parasitology. Vol.1. No.4. P.319-321 [in Russian, with English summary].

Rykovsky A.S. 1974. [Ecology and geography of helminths]. Moscow: Izdatel'stvo Nauka. 224 p. [In Russian]

Samojlovskaja N.A. 2008. [The comparative analysis of parasitofauna of spotty deers and lambs in national park "Losinyj island"] // Russian Journal of Parasitology. No.4. P.13-15 [in Russian, with English summary].

Samojlovskaja N.A. 2011. [Fauna of parasites of wild boars in national park "Losinyj island" (Moscow)] // Russian Journal of Parasitology. No.3. P.17-19 [in Russian, with English summary].

Samojlovskaja N.A. Gorohov V.V. \& Malakhova E.I. 2013. [Methods of epizootological examination of strongylatoses of moose in specially protected natural areas] // Russian Journal of Parasitology. No.3. P.113-119 [in Russian].

Shakhmatova V.I. 1988. [A new species of the nematode of the genus Skrjabinagia Kassimov, 1942 (Nematoda, Trichostrongylidae) from a fossil bison] // Zolotarenko G.S. (ed.). Taksonomiya zhivotnykh Sibiri. Novosibirsk: Izdarel'stvo Nauka. P.9-14 [in Russian].

Shestakova S.V. \& Novikova T.V. 2009. [Helmintofauna of elk in Vologda region] // International Bulletin of Veterinary Medicine. No.1. P.15-19 [in Russian, with English summary].

Sokolov I.I. 1953. [The experience of the natural classification of Cavicorn] // Trudy Zoologicheskogo instituta AN SSSR. Vol.14. 295 p. [In Russian]

Soubrier J., Gower G., Chen K., Richards S.M., Llamas B. et al. 2016. Early cave art and ancient DNA record the origin of European bison // Nature Communications. No.7:13158. P.1-7. DOI: 10.1038/ncomms 13158 .

Subbotin A.M. 2011. [Parasitic systems of wild ungulates and carnivores and the basis for the prevention of parasites in Belarus]. PhD Thesis. Vitebsk: Vitebskyi Gosudarstvennyi Meditsinskyi Universitet. 48 p. [In Russian]

Treboganova N.V. 1997. [European bison parasites in the Central region of Russia: monitoring and prevention of disease]. PhD Thesis. Moscow: Vserossyiskyi Nauchnoissledovatelskyi Institut Prikladnoi Parazitologii Zhivotnykh i Rastenyi imeni K.I. Skryabina. 31 p. [In Russian]

Treboganova N.V. 2003. Prevention of helminthiases in farms (European bison) // Problemy sokhraneniya i vosstanovleniya dikikh kopytnykh zhivotnykh $\mathrm{v}$ tsentralnom regione Rossii. Orel: Izdatel'stvo Orlovskoi Regionalnoi Akademii Gosudarstvennoi Sluzhby. Vol.1. P.118-121 [in Russian].

Treboganova N.V., Moskvin A.S. \& Gorokhov V.V. 2005. [Helminthological assessment of pastures of the central European bison breeding center of Prioksko-Terrasny Reserve] // Brynskihk M.N. (ed.). Ecosistems of Prioksko-Terrasny Nature Biosphere Reserve. Puschino: Izdatel'stvo Biopress. P.190-199 [in Russian]. 